\title{
RESPONSE TO RUTH GILBERT, "JEWISH GENDER STUDIES AND CONTEMPORARY LITERARY CRITICISM”
}

\author{
Tamar S. Drukker*
}

\begin{abstract}
This paper offers a brief overview of several key developments in modern Hebrew Israeli literature, moments where the female voice, of authors, poets and literary characters, paves the way to different sensitivities and voices in a seemingly hegemonic and strongly-ideological literary corpus. It aims to show that just like in world literature, in Jewish literature and in literary criticism, the rise of feminist readings opened the way to a variety of alternative voices, identities and otherness.
\end{abstract}

Ruth Gilbert offers readers a brief, yet detailed and illuminating overview of the main themes and questions in gender studies and their uses for literary criticism in Jewish literature, and the many examples of the characterization of both Jewish men and women in a rich and diverse corpus. It is interesting to note that Gilbert begins and ends with queer studies as a development of feminist readings and theory, a field where masculine and feminine identities of Jewish characters are fluid, constantlychanging and these identities re-examine perceived norms and cultural expectations.

I would like to take these theories and test them out on modern Hebrew literature produced in Israel. For most of the twentieth century this literature offered a voice to a culture obsessed with masculinity. Fearing and rejecting Boyarin's effeminate Jew, modern Hebrew literature gives room to a new man; the anti-diaspora muscular new Hebrew, active, strong and virile. 'This is the heroic Zionist fighter and lover familiar to English readers in the image of Ari Ben Canaan from Leon Uris' Exodus (1958) and numerous male protagonists in Hebrew fiction, perhaps most iconic is Uri Kahana in Moshe Shamir's 1947 novel He Walked through the Fields. The story of the nation is told in the fictional biography of these young men, and from the 1930s through to the 1980s, and some would argue still today, modern Hebrew literature was devoted to history. Women's writing dealt with the domestic and emotional life of individuals outside or on the fringe of national narrative.

In a literary landscape populated by "Ari"s and "Uri"s, the appearance of N'ima Sassoon in 1963 caused a minor earthquake. ${ }^{2}$ The narrator of this short story is a twelve-year-old Mizrahi girl in a religious Jewish school in a small town in Israel; a new literary type, an Israeli, Hebrew-speaking, Mizrahi female young artist.

N'ima's voice and poetry are a complete new addition to the "soundtrack" of Hebrew literature, and not only because she is a woman. This female voice is also religious, and Mizrahi, and the language, setting, and characters of this story offer an alternative to the seemingly uniform Israeli Hebrew literature. The author, Amalia Kahana-Carmon (1926-2019), is a product and a member of this dominant Zionist new Hebrew culture. Kahana-Carmon was born in a kibbutz, was raised in Tel Aviv, she was a member of the Palmach and she fought in 1948, and yet, when offering a female voice in Hebrew letters, the feminine gives way to the Other, and for many, especially Mizrahi women, N'ima Sassoon paved the way for their own literary creative life.

\footnotetext{
* Senior Lecturer in Hebrew, School of Languages, Cultures and Linguistics, SOAS, University of London, UK. Email: td4@soas.ac.uk

Daniel Boyarin, "Masada or Yavneh? Gender and the arts of Jewish resistance," in Jonathan Boyarin and Daniel Boyarin, eds., Jews and Other Differences: The New Jewish Cultural Studies, (Minneapolis: University of Minnesota Press, 1996). On the Zionist male alternative see David Biale, Eros and the Jews: From Biblical Israel to Contemporary America (Berkeley, Los Angeles and London: University of California Press, 1992) and Oz Almog, The Sabra: The Creation of the New Jew, trans. Haim Watzman (Berkeley, Los Angeles and London: University of California Press, 2000).

"2 Amalia Kahana-Carmon, "N'ima Sasson writes poems," English translation available in the collection Benjamin Tammuz and Leon I. Yudkin, eds., Meetings with the Angel: Seven Stories from Israel (London: Andre Deutch, 1973).

${ }^{3}$ Ronit Matalon (1959-2017) in an informal discussion expressed her debt and gratitude to Kahana-Carmon's story as the literary text that suggested to her that she too could become a writer (in conversation with Ronit Matalon, Cambridge, June 2017). On KahanaCarmon's role as a female author see Lily Rattock, The Other Voice: Women's Fiction in Hebrew [Hebrew] (Tel Aviv: Hasifria
} 
N'ima remained alone for a while, and interestingly, the female narrators who joined her in the following decades were often written by male authors. This is not unique to Israeli Hebrew literature, but some of the most memorably and influential first-person female narrators in Hebrew are the creation of male authors, from the grieving orphaned daughter Tirza in S. Y. Agnon's "In the Prime of her Life" (1932) to the hyper-conscious and disturbed Hannah Gonen in Amos Oz's My Michael (1966). And while the female voice allows for a more nuanced and sensitive study of character, love, desire and especially family, they still partake in the greater narrative of the history of the Jewish people and in nation building.

A different use of the feminine voice by a male author is found in Sami Michael's $A$ Trumpet in the Wadi first published in 1987. The angry anti-establishment author of All Men are Equal - But Some are More (1974), the Iraqi-born communist who dared describe the racism, discrimination and inequality in Jewish Israeli society, takes up, twenty years after the appearance of N'ima Sassoon and Hannah Gonen, the first-person voice of a Christian Arab young woman living in Haifa. Choosing the female voice, in a novel that is almost a mirror opposite of Oz's classic, Sami Michael tells us the story of the ultimate Other, a voice almost absent from, or mute in Hebrew literature.

Ammiel Alcalay was among the first scholars of Hebrew Mizrahi literature to highlight the limits of cultural studies and gender studies when reading non-Western texts. 'Perhaps the next phase for both male and female writers in Hebrew is the move towards representation of non-binary sexual identities, a look into alternative family structures and relationships. And if we follow the chain of female characters whose love is unanswered, unhappy or tragic, a love which gives them their creative voice and identity, be it in poetry, madness or resignation, N'ima Sassoon, Hannan Gonen and Huda have taught us how to read and write the Other, in the way that gender and queer studies open up new possibilities and new meanings.

\section{BIBLIOGRAPHY}

Agnon, S. Y. "In the Prime of her Life," in Alan Lelchuk and Gershon Shaked, eds., 8 Great Hebrew Short Novels. Translated by Gabriel Levin. New Milford: Toby Press, 2005.

Alcalay, Ammiel. After Jews and Arabs: Remaking Levantine Culture. Minneapolis and London: University of Minnesota Press, 1993.

Almog, Oz. The Sabra: The Creation of the New Jew. Translated by Haim Watzman. Berkeley, Los Angeles and London: University of California Press, 2000.

Biale, David. Eros and the Jews: From Biblical Israel to Contemporary America. Berkeley, Los Angeles and London: University of California Press, 1992.

Boyarin, Daniel. "Masada or Yavneh? Gender and the Arts of Jewish Resistance,” in Jonathan Boyarin and Daniel Boyarin, eds., Jews and Other Differences: The New Jewish Cultural Studies. Minneapolis: University of Minnesota Press, 1996.

Fuchs, Esther. “Amalia Kahana-Carmon and Contemporary Hebrew Women's Fiction,” in Esther Fuchs, ed., Israeli Women's Studies: A Reader. New Brunswick and London: Rutgers University Press, 2005.

Kahana-Carmon, Amalia. "N'ima Sasson writes poems," in Benjamin Tammuz and Leon I. Yudkin, eds., Meetings with the Angel: Seven Stories from Israel. London: Andre Deutch, 1973.

Michael, Sami. All Men are Equal - But Some are More [Hebrew]. Tel Aviv: Bustan, 1974.

Michael, Sami. A Trumpet in the Wadi. Translated by Yael Lotan. New York: Simon \& Schuster, 2003. Oz, Amos. My Michael. Translated by Nicholas de Lange. London: Chatto \& Windus, 1972.

Hachadasha, 1994) and Esther Fuchs, “Amalia Kahana-Carmon and Contemporary Hebrew Women's Fiction,” in Esther Fuchs, ed., Israeli Women's Studies: A Reader (New Brunswick and London: Rutgers University Press, 2005).

"Ammiel Alcalay, After.Jews and Arabs: Remaking Levantine Culture (Minneapolis and London: University of Minnesota Press, 1993). See also Ella Shohat, "Gendered Cartographies of Knowledge: Area Studies, Ethnic Studies and Postcolonial Studies," in Taboo Memories, Diasporic Voices (Durham: Duke University Press, 2006). 
Rattock, Lily. The Other Voice: Women's Fiction in Hebrew [Hebrew]. Tel Aviv: Hasifria Hachadash, 1994.

Shamir, Moshe. He Walked Through the Fields. Play based on the novel. Jerusalem: World Zionist Organization, 1958.

Shohat, Ella. "Gendered Cartographies of Knowledge: Area Studies, Ethnic Studies and Postcolonial Studies,” in Taboo Memories, Diasporic Voices. Durham: Duke University Press, 2006.

Uris, Leon. Exodus. Garden City New York: Doubleday, 1958. 


\section{DISCUSSION POINTS FOLLOWING THE PAPER BY RUTH GILBERT AND THE RESPONSE BY TAMAR DRUKKER}

To what extent are problematic aspects of gender representations specific to Jewish characters or a universal phenomenon?

The relationship between Jewish feminism and the larger field of women's studies and gender studies is perceived as unconstructive and hostile: is this caused by perceptions of Jewish women as enjoying white privilege, while neglecting Jewish otherness?

Is queerness useful to challenge binary gender categorization in literary criticism?

Does queer theory connect with real queer people and identities? 